\title{
A study of ovarian tumors at Kathmandu medical college teaching hospital
}

\author{
Pradhan Sailesh Bahadur ${ }^{1}$, Chalise Sanat ${ }^{1}$, Pradhan Binita ${ }^{2}$, Maharjan Sailuja ${ }^{3}$ \\ ${ }^{I}$ Department of Pathology, Kathmandu Medical College teaching hospital, Kathmandu, Nepal. \\ ${ }^{2}$ Department of Emergency, Kathmandu Medical College teaching hospital, Kathmandu, Nepal. \\ ${ }^{3}$ Department of Pathology, Kathmandu Medical College teaching hospital, Kathmandu, Nepal.
}

\section{Keywords: \\ Benign; \\ Borderline; \\ Malignant tumour; \\ Ovary; \\ Teratoma}

\begin{abstract}
Background: Ovarian cysts, which present as neoplastic and non-neoplastic lesions, are the most common gynecological cause of hospital admissions. This study was conducted to know the spectrum of ovarian tumors.

Materials and Methods: A cross sectional study was carried out among all the ovarian specimens sent for histopathological examination.

Results: Germ cell tumour comprises $53.85 \%$ followed by Surface epithelial tumours $45.05 \%$ and metastatic tumour $1.1 \%$. Among surface epithelial tumours, $82.9 \%$ were benign neoplasm, $4.9 \%$ were borderline and $12.2 \%$ were malignant. Among all Germ cell tumours, 45 (91.84\%) were Mature cystic teratoma, 2 (4.08\%) was Immature cystic teratoma and 2 (4.08\%) were Dysgerminoma.
\end{abstract}

Conclusion: Incidence of Surface epithelial tumours and germ cell tumours were found to be almost equal with mild predominance of Germ cell tumour.

\section{Correspondence:}

Dr. Sailesh Bahadur Pradhan, MBBS, MD

Associate Professor, Department of Pathology

Kathmandu Medical College teaching hospital, Kathmandu, Nepal ORCID ID: 0000-0002-0784-1836

Email: saibinita@gmail.com

Received : July 15th, 2017 ; Accepted : August 15th, 2017; Published : September 1, 2017

Citation: Pradhan SB, Chalise S, Pradhan B, Maharjan S. A study of ovarian tumors at Kathmandu medical college teaching hospital. J Pathol Nep. 2017;7: 1188-91. doi: 10.3126/jpn.v7i2.18004

Copyright: This is an open-access article distributed under the terms of the Creative Commons Attribution 4.0 International License, which permits unrestricted use, distribution, and reproduction in any medium, provided the original author and source are credited.

\section{INTRODUCTION}

Ovarian cancer is the most frequent cause of death from gynecological cancer. ${ }^{1}$ The incidence of ovarian neoplasm was $16.7 \%$ among total gynecological admission and the fourth most frequent cause of death from a cancer in women in Europe and US. ${ }^{2}$

Most of the ovarian lesions are presented with cyst formation which can be of physiological or pathological. ${ }^{3}$ Pathological cysts are mainly ovarian tumours which can be benign, borderline or malignant. ${ }^{3}$ Benign ovarian cyst may occur at any age but they are mostly seen during reproductive age 
and constitute about $90 \%$ of ovarian tumour. ${ }^{4}$

Due to their location, lack of regular screening and lack of specific symptoms, ovarian tumour often go undetected until they attain large size and present at a later age. ${ }^{5}$

The nature of ovarian cystic lesions is difficult to determine by clinical examination and even on surgical exploration. As the management and prognosis mainly depend on the histological type and the grade of the tumor, it is mandatory to find out the origin and the type of tumor by doing thorough histopathological examination. ${ }^{6,7}$ In this study, we have analyzed the histopathological types of ovarian tumours with frequency and age distribution.

\section{MATERIALS AND METHODS}

This is a cross sectional study carried out in Department of Pathology, Kathmandu Medical College Teaching Hospital (KMCTH) during the period of eighteen months from January 2016 to June 2017. Ethical clearance was obtained from the IRC in KMCTH. All the histopathologically proven ovarian tumour specimens of ovarian lesion received in Department of Pathology were included in the study. The tissues were processed by routine tissue processing. The paraffin blocks were made and sections stained with Haematoxylin and Eosin. Histopathological diagnosis was correlated with age of the patient and ovary involvement (unilateral or bilateral). Statistical analysis was performed using Microsoft Excel.

\section{RESULTS}

A total of 91 cases of ovarian lesions were studied. Among these, 41 cases were surface epithelial tumours, 49 cases were germ cell tumour and 1 case was metastatic carcinoma (Table 1).

Various tumors are seen in various age groups which is shown in table 2. Most of the ovarian tumour was found in 21- 30 years age group (41.76\%) followed by $41-50$ years age group (23.07\%). Mature cystic teratoma was seen predominantly in the $21-30$ years age-group $(n=26 ; 28.5 \%)$.

Among Surface epithelial tumours, 82.9\% were benign neoplasm, $4.9 \%$ were borderline and $12.2 \%$ were malignant neoplasm (Table 1). Serous cystadenoma was found to be the commonest among benign surface epithelial tumour followed by Mucinous cystadenoma. Out of 5 primary surface epithelial malignant cases, serous cystadenocarcinoma was the commonest.

Among all Germ cell tumours (Table 3), Mature cystic teratoma was found to be the commonest comprising $91.84 \%$, followed by Immature cystic teratoma $4.08 \%$ and Dysgerminoma $4.08 \%$.
Among 91 cases, 92.31\% were unilateral either right or left and $7.69 \%$ were bilateral. Right ovary was commonly involved among Surface epithelial tumour in comparison to left ovary (Table 3) Regarding Germ cell tumour, both right and left ovaries were found to be almost equally involved. Out of 7 bilateral cases, $57.14 \%$ were Mature cystic teratoma which is $4.4 \%$ of all ovarian neoplasm (Table 4 ).

\section{DISCUSSION}

Cystic lesions of the ovary are one of the commonest specimens that is received in the Pathology lab for the histopathological examination. Due to the similar clinical presentation of both non-neoplastic and neoplastic lesions of ovary, histopathological examination remains important for the proper management of tumour. ${ }^{8}$

The incidence of benign tumour was found to be $86.8 \%$ and malignant tumour was $11.0 \%$ with borderline tumour comprising $2.2 \%$. The findings were similar in a study done in Nepal by Jha $\mathrm{R}$ et $\mathrm{al}^{9}$ and Pudasaini $\mathrm{S}$ et al. ${ }^{3}$ In a study done by Pudasaini $\mathrm{S}$ et al. ${ }^{3}$, benign tumour was found to be $87.3 \%$ and malignant was $12.7 \%$. Similarly, $83.9 \%$ was benign and $16.1 \%$ was malignant in a study of Jha $\mathrm{R}$ et al. ${ }^{9}$ The incidence was found to be less in a study done by Ahmed $\mathrm{Z}$ et $\mathrm{al}^{10}$ where benign tumour was found to be only $59.2 \%$ and malignancy was high comprising 40.8 percent.

In our study, Germ cell tumour was found to be the commonest comprising 53.85percent. The findings were similar in the other studies. ${ }^{9-12}$ However it was found to be the second most common in other studies. ${ }^{3,9}$ Mature cystic tumour was the commonest tumour in our study comprising $49.45 \%$ of all ovarian primary tumours and $91.84 \%$ of all Germ cell tumour. The findings were similar with the findings of other studies ${ }^{3,9}$ however it was found to be the third commonest tumour in a study done by Prabhakar BR et al. ${ }^{13}$

In the western world, 95\% of ovarian Germ cell tumours were mature cystic tumour and only $3 \%$ of ovarian tumours are immature. ${ }^{14,15}$ Here in this study $4.08 \%$ of ovarian Germ cell tumour were found to be immature. Malignant germ cell tumours are the most common ovarian cancers among children and adolescent. ${ }^{15}$ Immature teratoma form $10-20 \%$ of ovarian cancers occurring in 1st two decade of life. ${ }^{14}$ In this study, 7 ovarian tumours were seen in $1^{\text {st }}$ two decade, out of which 3 were germ cell tumour comprising one Immature teratoma $(14.3 \%)$.

The second most common tumour was found to be Surface epithelial tumour comprising $45.55 \%$ of the entire primary ovarian tumour whereas in a study done by Jha $\mathrm{R}$ et $\mathrm{al}^{9}$ it was $52.2 \%$. Similarly it was found to be $70.9 \%$ and $63.5 \%$ in studies done by Pilli GS et al. ${ }^{16}$ and Ahmad Z et al $^{10}$ respectively. Malignant Surface epithelial tumours constituted $69.2 \%$ of all ovarian malignancies ${ }^{9}$ and in 
Table 1: Frequency of Benign, borderline and malignant ovarian tumours

\begin{tabular}{lcccc}
\hline Class type of tumour & Benign & Borderline & Malignant & Total \\
\hline Surface epithelial & $34(43.04 \%)$ & 2 & $5(50.0 \%)$ & $41(45.05 \%)$ \\
Germ cell & $45(56.96 \%)$ & & $4(40.0 \%)$ & $49(53.85 \%)$ \\
Metastatic & & & $1(10.0 \%)$ & $01(1.1 \%)$ \\
\hline Total & $\mathbf{7 9}(\mathbf{8 6 . 8} \%)$ & $\mathbf{2 ( 2 . 2 \% )}$ & $\mathbf{1 0}(\mathbf{1 1 . 0} \%)$ & $\mathbf{9 1}(\mathbf{1 0 0} \%)$ \\
\hline
\end{tabular}

Table 2: Age wise distribution of ovarian tumours $(n=91)$

\begin{tabular}{|c|c|c|c|c|c|c|c|}
\hline \multirow[t]{2}{*}{ Histopathological Diagnosis } & \multirow[b]{2}{*}{$10-20$} & \multicolumn{4}{|c|}{ Age group (years) } & \multicolumn{2}{|r|}{ Total } \\
\hline & & $21-30$ & $31-40$ & $41-50$ & $51-60$ & $>60$ & \\
\hline Mature cystic teratoma & 2 & 26 & 8 & 8 & & 1 & $45(49.45 \%)$ \\
\hline Serous cystadenoma & 2 & 4 & 3 & 8 & 1 & 3 & $21(23.077 \%)$ \\
\hline Mucinous cystadenoma & 2 & 6 & & 2 & 1 & 2 & $13(14.29 \%)$ \\
\hline Serous cystadenocarcinoma & & & 3 & & & & $3(3.3 \%)$ \\
\hline Immature cystic teratoma & 1 & & 1 & & & & $2(2.2 \%)$ \\
\hline Dysgerminoma & & 2 & & & & & $2(2.2 \%)$ \\
\hline Serous borderline & & & & 1 & & & $1(1.099 \%)$ \\
\hline Mucinous borderline & & & & 1 & & & $1(1.099 \%)$ \\
\hline Mucinous cysadenocarcinoma & & & 1 & & & & $1(1.099 \%)$ \\
\hline Endometroid carcinoma & & & & 1 & & & $1(1.099 \%)$ \\
\hline Krukenberg tumour & & & & & 1 & & $1(1.099 \%)$ \\
\hline Total & $7(7.69 \%)$ & $38(41.76 \%)$ & $16(17.58 \%)$ & $21(23.07 \%)$ & $3(3.3 \%)$ & $6(6.6 \%)$ & $91(100 \%)$ \\
\hline
\end{tabular}

Table 3: Frequency of epithelial tumours $(n=42)$

\begin{tabular}{|c|c|c|c|c|c|}
\hline \multicolumn{2}{|c|}{ Histopathological Diagnosis } & \multirow{2}{*}{$\begin{array}{c}\text { Percentage } \\
21(50.0 \%)\end{array}$} & \multirow{2}{*}{$\begin{array}{c}\text { Left ovary } \\
4\end{array}$} & \multirow{2}{*}{$\frac{\text { Right Ovary }}{16}$} & \multirow{2}{*}{$\begin{array}{c}\text { Bilateral } \\
1\end{array}$} \\
\hline & Serous cystadenoma & & & & \\
\hline \multirow[t]{2}{*}{ Benign } & Mucinous cystadenoma & $13(13.95 \%)$ & 6 & 7 & \\
\hline & Total & $34(80.95 \%)$ & $10(23.81 \%)$ & $23(54.76 \%)$ & $1(2.38 \%)$ \\
\hline \multirow{3}{*}{ Borderline } & Serous borderline & $1(2.38 \%)$ & & 1 & \\
\hline & Mucinous borderline & $1(2.38 \%)$ & & 1 & \\
\hline & Total & $2(4.76 \%)$ & & $2(4.76 \%)$ & \\
\hline \multirow{3}{*}{ Malignant } & Serous cystadenocarcinoma & $3(7.14 \%)$ & 2 & & 1 \\
\hline & Mucinous cystadenocarcinoma & $1(2.38 \%)$ & & & 1 \\
\hline & Endometroid carcinoma & $1(2.38 \%)$ & & 1 & \\
\hline Metastatic & Krukenburg tumour & $1(2.38 \%)$ & & 1 & \\
\hline Total & & $42(100 \%)$ & $12(28.57 \%)$ & $27(64.29 \%)$ & $3(7.14 \%)$ \\
\hline
\end{tabular}

our study it was found to be $55.55 \%$. Among all ovarian tumours, Serous cystadenoma comprises $23.08 \%$ followed by Mucinous cystadenoma $14.3 \%$. In other studies, it constitutes $35.4 \%, \quad 32.7 \%$ and $42.9 \% .^{9,13,16}$ Mucinous tumour constitutes $17 \%$ of all ovarian tumours in this study which was $16.8 \%, 25.0 \%$ and $25.5 \%$ in other studies. ${ }^{9,13,16}$ Out of all serous tumours, $84.0 \%$ were benign \& $12.0 \%$ were malignant which was $78.9 \%$ and $21 . \%$ respectively in a study done by Jha $\mathrm{R}$ et $\mathrm{al}^{9}$. Similarly, out of all mucinous tumours, $86.67 \%$ were benign and $6.67 \%$ were malignant which was $77.8 \%$ and $22.2 \%$ in a study done by Jha R et al. ${ }^{9}$ Serous borderline was $4.0 \%$ among all serous tumour and $6.67 \%$ was Mucinous borderline among all mucinous tumour.
Ovarian tumour was found to be more common among the age group of 21-30 years. A total of $41.76 \%$ tumours were found in this group followed by $41-50$ years age group comprising 23.07 percent. The finding were similar in a study done by Kayastha $\mathrm{S}$ et $\mathrm{al}^{2}$ and Pudasaini $\mathrm{S}$ et al. ${ }^{3}$ However in a study done Maharjan $\mathrm{S}$ et $\mathrm{al}^{17}$, it was found to be most common in the age group of 31-40 years comprising $41.0 \%$ followed by $21-30$ years age group..

The primary ovarian tumors were mostly unilateral. In this study, 92.3\% were unilateral either right or left and $7.69 \%$ were bilateral. Right ovary was commonly involved among surface epithelial tumour $64.28 \%$ in comparison to left ovary 28.57 percent. Regarding germ cell tumour, both 
Table 4: Frequency of germ cell tumour $(n=49)$

\begin{tabular}{|c|c|c|c|c|c|}
\hline \multicolumn{2}{|c|}{ Histopathological Diagnosis } & \multirow{2}{*}{$\begin{array}{l}\text { Percentage } \\
45(91.84 \%)\end{array}$} & \multirow{2}{*}{$\begin{array}{c}\text { Left ovary } \\
19\end{array}$} & \multirow{2}{*}{$\begin{array}{c}\text { Right Ovary } \\
22\end{array}$} & \multirow{2}{*}{$\frac{\text { Bilateral }}{4}$} \\
\hline & Mature cystic teratoma & & & & \\
\hline Teratoma & Immature cystic teratoma & $2(4.08 \%)$ & 2 & & \\
\hline Dysgermin & & $2(4.08 \%)$ & 1 & 1 & \\
\hline Total & & $49(100 \%)$ & $22(45.0 \%)$ & $23(46.9 \%)$ & $4(8.1 \%)$ \\
\hline
\end{tabular}

right and left ovaries were found to equally involved. Out of $7.7 \%$ bilateral cases, $42.86 \%$ were epithelial origin and $57.14 \%$ were germ cell origin. The incidence of bilaterality was found to be higher in a study done by Kanthikar SN et $\mathrm{al}^{18}$ where bilaterality was found in $21.82 \%$ but Madan A et $\mathrm{al}^{19}$ and Verma $\mathrm{K}$ et $\mathrm{al}^{20}$ observed low incidence of bilaterality in $11 \%$ and $11.91 \%$ respectively. Regarding bilateral presentation of mature cystic teratoma, the figures are similar with the findings of a study done by Maharjan S et al. ${ }^{17}$

\section{CONSLUSION}

Ovarian cystic lesions present from prepubertal to the postmenopausal age. The ovarian cystic lesion behaves in diverse ways. As there is lack of specific symptoms and signs, which suggest malignant nature, these cysts require excision for histopathological examination based on which proper patient management can be done.

\section{Conflict of interest: None}

\section{REFERENCES}

1. Jacobs IJ, Menon U. Progress and challenges in screening for early detection of ovarian cancer. Mol Cell Proteomics 2004;3:355-66. Crossref

2. Kayastha S. Study of ovarian tumors in Nepal Medical College Teaching Hospital. Nepal Med Coll J 2009;1:200-2.

3. Pudasaini S, Lakhey M, Hirachand S, Akhter J, Thapa B. A study of ovarian cyst in a tertiary hospital of Kathmandu valley Nepal Med Coll J 2011;13:39-41. Crossref

4. Day N.E, Krishnan E. Epidemiology of gynaecological cancers. Gynaecology by Shaw R W. 2nd edn.Churchill Living Stone; Edinburgh: 1997. p 477-87.

5. Bhagyalakshmi A, Sreelekha A, Sridevi S, Chandralekha J, Parvathi G, Venkatalakshmi A. Prospective study of histopathological patterns of ovarian tumours in a tertiary care centre. Int J Res Med Sci. 2014;2:448-56. Crossref
6. Hasan Y, Rizvi G, Pandey HS. Histological pattern of Ovarian Tumors in a Tertiary care Hospital in Kumaon Region of Uttarakhand: A five year Retro-Prospective Study. Journal of Evolution of Medical and Dental Sciences. 2014;3:2536-42. Crossref

7. Dhakal R, Makaju R, Bastakoti R. Clinico-morphological Spectrum of Ovarian Cystic Lesions. Kathmandu Univ Med J 2016;53:13-6.

8. Bhattacharya MM, Shinde SD, Purandre VN. A clinicopathological analysis of 270 ovarian tumours. J Postgrad Med. 1980;26:103-7. Crossref

9. Jha R, Karki S. Histological pattern of ovarian tumours and their age distribution. Nepal Med Coll J 2008;10: 81-5. Crossref

10. Ahmad Z, Kayani N, Hasan SH, Muzaffar S, Gill MS. Histological pattern of ovarian neoplasm. Pak Med Assoc 2000;50:416-9.

11. Singhal SR, Rattan KN, Nanda S, Singhal SK. A 9- year review of ovarian masses in children and adolescents. J Gynecol Surg. 2008;24:113-6. Crossref

12. Koonings PP, Campbell K, Mishell DR, Grimes DA. Relative frequency of primary ovarian neoplasms: a 10 year review. Obstet Gynaecol 1989;74:921-6. Crossref

13. Prabhaker BR, Maingi K. Ovarian tumours- prevalence in Punjab. Indian J Pathol Microbiol 1989;32:276-81.

14. Scully Robert E, Young Robert H, Clement Phillip B. Atlas of Tumor Pathology. Tumors of the ovary, maldeveloped gonads, fallopian tube and broad ligament. 3rd series, Fascicle 23. Armed Force Institute of Pathology, 1999.

15. Tavassoli FA, Devilee P. WHO Classification of Tumors.Pathology and Genetics, Tumors of Breast and Female Genital Organs. IARC Press: Lyon 2003. Crossref

16. Pilli GS, Suneeta KP, Dhaded AV, Yenni VV. Ovarian tumours: a study of 282 cases. J Indian Med Assoc 2002;100:423-4.

17. Maharjan S. Clinicomorphological study of ovarian lesions. Journal of Chitwan Medical College. 2013;3:17-24.

18. Kanthikar SN, Dravid NV, Deore PN, Nikumbh DB, Suryawanshi KH. Clinico-Histopathological Analysis of Neoplstic and NonNeoplastic Ovarian Lesions of the Ovary: A 3 year Prospective Study in Dhule, North Maharashtra, India. J Clin Diagn Res. 2014;8:4-7.

19. Madan A, Tyagi SP, Mohsin S. Incidence of ovarian tumours at Aligargh with particular reference to histopathological typing. J Obstet Gynecol India.1978;8:27-32.

20. Verma K, Bhatia A. Ovarian neoplasms- A study of 403 tumours. J Obstet Gynaecol India.1981;40:6-11. 